\title{
Using radioelement distributions to classify a composite granite batholith in the South West England Orefield
}

\author{
Christopher M. Yeomans ${ }^{1,2}$, Robin K. Shail ${ }^{1}$, Paul A. Lusty ${ }^{2}$, Stephen Grebby ${ }^{2}$, Mark \\ Smethurst ${ }^{1,3}$ and David Beamish ${ }^{2}$ \\ ${ }^{1}$ Camborne School of Mines, University of Exeter, Penryn Campus, Penryn, \\ Cornwall, TR10 9FE (chrisy@bgs.ac.uk) \\ ${ }^{2}$ British Geological Survey, Environmental Science Centre, Keyworth, \\ Nottinghamshire, NG12 5GG \\ ${ }^{3}$ Avalonia Geophysics, Penryn Campus, Penryn, Cornwall, TR10 9FE, UK
}

The South West England Orefield is well-known for its polymetallic magmatichydrothermal mineralisation associated with the composite Cornubian granite batholith. The mineralisation contains elevated concentrations of a range of metals (e.g. $\mathrm{W}, \mathrm{Sb}, \mathrm{Bi}, \mathrm{As}, \mathrm{Be}, \mathrm{Cd}, \mathrm{Ga}, \mathrm{Ge}, \mathrm{In}, \mathrm{Li}, \mathrm{Nb}, \mathrm{Ta}$ ) used in high-technology and clean energy applications and for which security of supply concerns exist [1,2,3]. Exploration for these elements requires improved understanding of the spatial distribution of granite types and their relationship to the different mineralisation styles and parageneses. Previous granite classifications defined granite types based on mineralogical and/or textural observations from field sampling [e.g. 4]. However, these divisions over simplify mineralogical variation (e.g. micas), and the sample density is inadequate to reflect the heterogeneity of the batholith. Classifications based on whole-rock geochemistry, provide a more objective classification method [e.g. 5] and can guide mineral exploration, particularly in poorly exposed areas.

The Tellus South West Survey collected airborne radiometric data over the surface extent of the granites. This continuous sample set has allowed us to produce a 'geochemical' classification of the granites using potassium, thorium and uranium concentrations calculated from gamma-ray emissions. The gridded data were manipulated as ratios and relative abundances [6]. Principal Component Analysis was used to reduce noise from spurious pixels associated with high water content in peat. These spurious pixels were subsequently removed using a 'supervised' classification (Minimum-Distance). The data were standardised to zero mean and equal variance.

An 'unsupervised' classification (K-means) was used to automatically and objectively classify the remaining data in 9-dimensional space (based on the input variables). Six classes were found to be optimum for delineating geochemical variations within the granites. Here, we present this new classification of the granites using continuous data covering the whole batholith. We also consider how to incorporate ground-based geochemical and satellite multispectral (Landsat) data into the classification.

\footnotetext{
References

[1] Simons et al. (2013) Distribution of critical metals in biotite and Li mica granite from Cornwall, UK. $36^{\text {th }}$ Annual Winter Meeting of the Mineral Deposit Studies Group, Leicester $2^{\text {nd }}-4^{\text {th }}$ January 2013

[2] European Commission (2014) Report on critical raw materials for the EU. Report of the Ad hoc Working Group on Defining critical raw materials, May 2014. Ref. Ares(2015)1819503 - 29/04/2015

[3] British Geological Survey (2012) Risk List 2012. Available from http://www.bgs.ac.uk/mineralsuk/statistics/risklist.html

[4] Dangerfield \& Hawkes (1981) The Variscan Granites of south-west England additional information. Proceedings of the

Ussher Society, 5: 116-120

[5] Manning et al. (1996) Primary lithological variation in the kaolinized St Austell Granite, Cornwall, England. Journal of the

Geological Society, London, 153: 827-838

[6] IAEA (2003) Guidelines for radioelement mapping using gamma ray spectrometry data. IAEA, Vienna, Austria
} 